\title{
КОРЕННЫЕ НАРОДЫ ОХОТСКО-КОЛЫМСКОГО КРАЯ В ГОДЫ ВЕЛИКОЙ ОТЕЧЕСТВЕННОЙ ВОЙНЫ
}

\author{
Хаховская Л. Н. \\ ФГБУН Северо-Восточный комплексный научно-исследовательский институт \\ им. Н. А. Шило ДВО РАН, г. Магадан \\ E-mail: hahovskaya@gmail.com
}

\begin{abstract}
На основе архивных источников автор анализирует положение коренных народов ОхотскоКолымского края в годы Великой Отечественной войны. Органы власти продолжали осуществлять патерналистскую социальную политику: обустройство жилищной и социальной инфраструктуры в местах проживания аборигенов, повышение уровня медицинского обслуживания и образования, профессиональное обучение. Показано, что основная масса колхозников-аборигенов дисциплинированно и ответственно трудились в сферах, связанных с традиционным природопользованием (оленеводство, рыболовство, пушная охота). Своим трудом и личными пожертвованиями коренные жители вносили посильный вклад в победу. Также они воевали на фронте и служили в тыловых войсках.

Ключевые слова: Великая Отечественная война, Охотско-Колымский край, коренные малочисленные народы Севера, социально-демографические процессы, традиционное природопользование, фронт, тыл.
\end{abstract}

DOI: $10.34078 / 1814-0998-2020-4-114-123$

\section{ВВЕДЕНИЕ}

Историография Великой Отечественной войны в последние десятилетия значительно расширилась по освещаемой тематике. В поле зрения авторов попали такие аспекты, как судьбы определенных групп населения, выделенных по социальному или территориальному признаку (крестьянство, женщины, народы Сибири); повседневная жизнь и быт населения тыла; особенности умонастроения и мировосприятия людей в эти суровые годы (Исупов, Алексеев, 1986; Анисков, 1998; Шалак, 1998; Зима, 2000; Горбулина, 2001; Советская..., 2003). Население северных окраин Советского Союза, в том числе коренные малочисленные народы Севера, не испытали тех ужасов, жертв и лишений, которые в годы Великой Отечественной войны выпали на долю жителей центральных районов страны. Однако на их исторические судьбы, тесно связанные с судьбами всех советских людей, военные события, безусловно, наложили неизгладимый отпечаток. Как и все трудящиеся, работавшие в тылу, аборигены Севера вносили посильный вклад в борьбу с захватчиками. Они разделяли общий патриотический настрой, трудовой подъем и желание помочь сражающимся бойцам Красной Армии. Задача нашей работы заключается в ис-

(C) Хаховская Л. Н., 2020 следовании особенностей положения коренных народов, проживавших на территории ОхотскоКолымского края, в годы Великой Отечественной войны.

Термин «Охотско-Колымский край», или регион, в данном случае имеет не только географические, но и административно-территориальные, а также экономические и этнические референции. Это территория трех национальных районов (Ольский, Среднеканский и Северо-Эвенский), изначально входивших в сферу деятельности хозяйственной структуры с особыми полномочиями - золотодобывающего треста «Дальстрой» (Гребенюк, 2007). Данный регион издавна являлся местом обитания аборигенов различной этнической принадлежности и происхождения. Мы осветим следующие вопросы: какова была социальная и демографическая обстановка у коренных жителей региона, какими путями шла перестройка аборигенной экономики и повседневного быта, как в среде коренных жителей преломлялись общие переживания и представления той эпохи, каков был личный вклад местных жителей в победу над врагом. Источниками исследования послужили первичные архивные документы, хранящиеся в Государственном архиве Магаданской области (ГАМО), а также исследования региональных историков (Козлов, 1986, 1996; Козлов, Райзман, 1996; Бацаев, 1997). 


\section{СОЦИАЛЬНО-ДЕМОГРАФИЧЕСКАЯ СИТУАЦИЯ}

Статистические данные показывают, что в период Великой Отечественной войны численность коренных жителей на территории ОхотскоКолымского региона снижалась (табл. 1). Основные причины снижения не связаны напрямую с влиянием именно военной обстановки. Такая тенденция возникла в предшествующие годы и была обусловлена естественными процессами в среде самих аборигенов, на которые, кроме того, повлияли советские экономические и социально-политические преобразования. Например, начавшаяся во второй половине 1930-х гг. коллективизация аборигенных хозяйств повлекла за собой перекочевки оленеводов (эвенов, части юкагиров) в отдаленные местности с целью избежать всяких контактов с советскими сотрудниками. Поэтому данная часть коренных жителей не охватывалась статистическим учетом. Миграции были характерны и для некоторых оседлых аборигенов например, часть якутов, ранее переселившихся в регион, в эти годы вернулась на свою историческую родину (Хаховская, 2009. С. 99).

Изменение численности других оседлых или преимущественно оседлых жителей (камчадалы, юкагиры) не зависело от механического движения, а определялось прежде всего внутренними факторами. Известно, что основными причинами повышенной смертности аборигенов в регионе являлись социально обусловленные заболевания, связанные с условиями жизни и уровнем санитарной культуры, - туберкулез, трахома, сифилис и др. [ГАМО, ф. Р-38, оп. 1, д. 24, л. 17]. Медицинские работники так оценивали ситуацию первой половины 1940-х гг.: «Статистика показывает, что прироста коренного населения нет, что смертность остается высокой и в особенности среди детей. Преимущественно умирают от туберкулезной инфекции. Это болезнь социальная, и корни ее уходят в далекое прошлое, когда люди вели кочевой образ жизни. Бу- дет лучшее питание, будет и здоровье. Второеизолячия детей от больных родителей» [ГАМО, ф. П-10, оп. 1, д. 89, л. 22].

В условиях военного времени перед органами советской власти стояла задача улучшить условия жизни коренного населения, для чего требовалось продолжать обустраивать места их обитания, создавать социальную и бытовую инфраструктуру, повышать общую грамотность и санитарную просвещенность. Эта деятельность стала закономерным продолжением патерналистской социальной политики государства по отношению к коренным народам, выработанной в предшествующие десятилетия. Во всех национальных районах Охотско-Колымского края за годы войны увеличилось количество учреждений здравоохранения, культуры, образования, велось жилищное строительство.

Размещение сети пунктов оказания медицинской помощи непосредственно в местах проживания аборигенов в эти годы являлось приоритетной задачей органов власти. Так, в Среднеканском районе на начало 1940 г. было 4 фельдшерских пункта, к началу 1945 г. организованы 4 врачебных участка, 4 фельдшерских участка, 3 фельдшерских пункта, 1 детский комбинат на 25 детей, 1 туберкулезный пункт, 1 дезинфекционный пункт, 1 стоматологический кабинет [ГАМО, ф. П-10, оп. 1, д. 89 , лл. 23,74$]$. В Ольском районе с апреля 1941 г. по январь 1945 г. открыты новые врачебные участки в с. Тауйск, Армань, Сиглан [ГАМО, ф. П-16, оп. 2 , д. 18, л. 4]. Но само наличие врачебных учреждений не снимало всех накопившихся проблем, так как с населением требовалось вести большую разъяснительную работу, убеждать обращаться за помощью, менять сложившиеся жизненные установки: « $B$ первые дни организации медицинской помощи в сельских советах ... очень много сил приходилось убивать медработникам, чтобы заставить народы Крайнего Севера - якутов, эвенов, орочей, юкагиров и других - посещать

Таблица 1. Динамика численности коренных жителей Охотско-Колымского края Table 1. Dynamics of the number of indigenous inhabitants in the Okhotsk-Kolyma region

\begin{tabular}{|c|c|c|c|c|}
\hline \multirow{2}{*}{ Этническая принадлежность } & \multicolumn{4}{|c|}{ Численность на начало года, чел. } \\
\hline & 1936 & 1940 & 1944 & 1945 \\
\hline Эвены & 3612 & \multirow{4}{*}{$\begin{array}{c}\text { Данные } \\
\text { отсутствуют }\end{array}$} & 2139 & \multirow{4}{*}{$\begin{array}{c}\text { Данные } \\
\text { отсутствуют }\end{array}$} \\
\hline Юкагиры & 150 & & 175 & \\
\hline Камчадалы* & 514 & & 784 & \\
\hline Якуты & 631 & & 592 & \\
\hline Итого & 4907 & 4758 & 3690 & 3437 \\
\hline
\end{tabular}

Примечание. Составлено по: [ГАМО, ф. Р-50, оп. 1, д. 16, л. 4; ф. Р-38, оп. 1, д. 10, лл. 10, 32, 87].

*Камчадалы - представители метисированного населения Охотского побережья, потомки от браков русских переселенцев с коренными жителями (эвенами, юкагирами, коряками, якутами). В рассматриваемый период не входили в официальный перечень коренных малочисленных народов Севера, но учитывались статистической службой Дальстроя. 
лечебные учреждения, ибо им веками и десятками тысяч лет оказывали помощь при заболевании, родах, несчастных случаях различные шаманы, повитухи и другие знахари, к которым они привыкли и больше им верили, чем в научную медицину. Но все же ... коренное население ... стало постепенно посещать лечебное учреждение. Посещуаемость значительно увеличилась, но это не говорит о том, что заболеваемость среди коренного населения также значительно увеличилась. Коренное население за медицинской помощтью стало обрашаться в лечебные учреждения, а не к услугам шаманов» [ГАМО, ф. П-10, оп. 1, д. 89, л. 24].

Большое внимание уделялось развитию школьного образования, ликвидации неграмотности и повышению общего культурного уровня населения. В Среднеканском районе для детей местных жителей были выстроены 4 начальные школы (с. Оротук, Сеймчан, Балыгычан, Нелемное) и одна неполная средняя школа в пос. Таскан. Если в 1940/41 учебном году национальными школами здесь было охвачено 118 учащихся, то в 1944/45 - 162 [ГАМО, ф. П-10, оп. 1, д. 89, лл. 70, 71]. В Ольском районе с апреля 1941 г. по январь 1945 г., в дополнение к начальным, были открыты новые неполно-средние школы в с. Сиглан, Тахтоямск, Ямск [ГАМО, ф. П-16, оп. 2, д. 18, л. 4]. К концу войны все дети коренных жителей Охотско-Колымского региона были охвачены как минимум начальным школьным образованием.

Большое значение для улучшения демографической ситуации приобретало улучшение жилищных условий. Согласно долгосрочному плану довоенного времени, к 1 января 1945 г. на Охотском побережье, в местах проживания коренного населения, предусматривалось построить 640 домов общей стоимостью 11 млн руб., что в основном покрыло бы потребность всех аборигенов в жилье. Фактически же было возведено 233 дома, дальнейшее строительство из-за недостатка средств и материалов свернули, поэтому жилищная проблема продолжала оставаться острой [ГАМО, ф. Р-38, оп.1, д. 24, л. 17]. В более благоприятных условиях находились жители Ольского района. Здесь было построено более 100 колхозных домов, 5 сельсоветов переведены на оседлый образ жизни [ГАМО, ф. П-16, оп. 2, д. 18, л. 4; Советы..., 1982. С. 107]. Правда, возведенные дома зачастую приходили в негодность, так как оленеводы не могли проживать в них круглый год и поддерживать в исправном состоянии. Не всегда высоким было и качество построек. Так, на второй партийной конференции Ольского района (январь 1945 г.) председатель колхоза «Имени 1 Мая» (с. Сиглан) И. В. Хабаров отмечал: «Наши колхозники перешли на оседльій образ жизни. Но надо сказать, что в этих домиках жить очень холодно, ибо требуется ка- питальный ремонт» [ГАМО, ф. Р-16, оп. 2, д. 18, л. 4].

Руководители Северо-Эвенского района считали важным привлечение самих колхозников к строительству и ремонту жилья, видя в этом некоторый «воспитательный» момент, т. е. возможность в ходе работы привить им полезные трудовые навыки. В число партийных забот входило также изменение бытовых норм поведения, формирование полезных привычек: «Райком ВКП(б) должен уделить особое внимание улучшению быта колхозников, а также их воспитанию, а именно помочь колхозникам отстроить и отремонтировать дома. Провести воспитание за соблюдение чистотьл. Выбросить из домов оленьи шкуры (рассадник вшей) и заменить другой одеждой, бельем и постельными принадлежностями, а также научить население бережно относиться к этим вещуам》 [ГАМО, ф. П-15, оп. 3, Д. 10, л. 19].

Безусловно, на этом пути происходила некоторая утрата традиционных ценностей, нивелирование культурного облика аборигенов, однако стоит отметить, что это были издержки крайней ограниченности ресурсов, стремления удовлетворить прежде всего первичные жизненные потребности, не поступаясь при этом и духовными запросами населения. Эффект от проводимой социальной политики даже в годы войны был достаточно убедительным. Об этом свидетельствуют, например, материалы по Среднеканском району: «Если в 1940 г. жители большинства сельских советов жили разбросанно, вели кочевой образ жизни, то за [военный] период население Оротукского, Эсчанского, Коркодонского, Нелемнского, Бальгычанского сельских советов получили благоустроенные национально-хозяйственные ичентры с достаточным количеством колхозных домиков, с наличием школ, изб-читален, больнии, ветпунктов, бань, магазинов, производственных помещений, перешли на оседльй образ жизни. Колхозники научились культурно содержать свои дома, регулярно посещзать баню, культурно приготовлять пищу, приобрели элементарные санитарногигиенические навыки. Местное население охотно посещчает кино, клубы, лекичи, доклады, вырос интерес к политике, науке» [ГАМО, ф. П-10, оп. 1, д. 89, л. 71].

В этот период органы власти строили и более амбициозные планы по культурному и профессиональному росту представителей коренного населения, стремились распространять не только массовое, но и специализированное образование, нацеливать молодых людей на продолжение учебы, решать проблему «коренизации» всех областей деятельности и управленческих звеньев. Эта задача во всей своей остроте стояла на повестке дня: «Недостаточно выращено у нас учителей, врачей, бухгалтеров, счетоводов из местного населения» [ГАМО, ф. П-16, оп. 2, д. 18, л. 6]. 
Вместе с тем основная масса коренного населения в это время продолжала трудиться в сфере традиционного природопользования, но уже в рамках новой, колхозной действительности. Эта привычная деятельность потребовала, однако, значительной перестройки трудового процесса, что вскрыло определенные социальные, организационные и ментальные трудности, в особенности обострившиеся в годы войны. Они заключались, прежде всего, в изменении характера труда, который стал предписанным, заранее задаваемым со стороны руководства. Аборигены в значительной степени утрачивали возможность самостоятельно принимать общие решения, но от них требовалась дисциплина, ответственность за результаты, более интенсивная и коллективно согласованная трудовая активность. Индивидуальный и/или семейный труд, который зачастую специализировался на каком-либо одном преимущественном виде деятельности и не предполагал достижения заданных количественных результатов, сменился обязательной работой в коллективных хозяйствах с их комплексной направленностью и плановостью. Эти значимые сдвиги, кроме того, выявили острые производственные проблемы, которые вытекали из малочисленности трудоспособных аборигенов-колхозников и влекли за собой невозможность достичь удовлетворительных показателей по всем отраслям хозяйства.

\section{ИНТЕНСИФИКАЦИЯ АБОРИГЕННОЙ ЭКОНОМИКИ}

Военная обстановка потребовала от органов власти существенной экономической перестройки, два направления которой напрямую касались коренных жителей. Первая задача состояла в максимальном использовании местных продовольственных ресурсов и уменьшении завоза с «материка». В связи с этим важное значение приобрели отрасли, непосредственно снабжавшие население продуктами: оленеводство, рыболовство, огородничество и животноводство. Вторая задача заключалась в повышении результативности тех сфер экономики, которые приносили валютную выручку, и здесь в аборигенном хозяйстве на первый план вышла пушная охота.

Трудовая мобилизация коренных жителей проходила в форме подтверждения приверженности социалистической идеологии. В приказе Главного управления строительства Дальстроя (ГУСДС) и Политуправления № 50 от 10 ноября 1941 г. говорилось: «Сельсоветы и колхозы долюсны беречь и укреплять общественную социиалистическую собственность как священную и неприкосновенную основу советского строя, как источник зажиточной и культурной жизни трудящихся. В час военных испытаний колхозники должны ещце теснее сомкнуть свои ряды вокруг великой партии Ленина - Сталина, удесятерить усилие, укреплять и расширять колхозное производство. Все силь на помощь нашей доблестной Красной Армии, нашей любимой Советской Родине» [ГАМО, ф. Р-38, оп. 1, д. 1, л. 81].

В приказе ГУСДС № 50 от 29 ноября 1941 г. подчеркивалось, что «в это грозное время, когда наш великий народ собрал все силь на борьбу с жестоким врагом, не должно быть отстаюших, не должно быть ни одного колхоза, не выполняюшего своих обязательств перед государством... Колхозы Кольмы должны перестроить свою работу на военный лад» [Там же].

На территории Охотско-Колымского края первоначальная коллективизация коренных жителей завершилась в довоенный период. В регионе практически не осталось единоличных хозяйств, хотя в личной собственности колхозников-аборигенов еще сохранялось значительное количество оленей. Более того, накануне войны, в 19391940 гг., все созданные коллективные хозяйства были переведены с устава северного смешанного товарищества на устав рыболовецкой или сельскохозяйственной артели, т. е. стали собственно колхозами. Всего накануне войны в регионе имелся 21 колхоз и 3 оленеводческих совхоза. Последние первоначально были созданы для обеспечения транспортных потребностей Дальстроя, но в годы войны начали выполнять роль поставщиков продовольствия.

В отличие от совхозов, специализировавшихся на оленеводстве, колымские колхозы с самого начала были комплексными, т. е. в своей деятельности сочетали все те отрасли хозяйствования, которые были присущи вошедшему в них коренному населению. В обстановке военного времени государство требовало постоянно наращивать производство продукции всех этих отраслей. Количественные показатели, характеризующие состояние общественного хозяйства, в годы войны постоянно возрастали, что отражено в табл. 2.

Приведенные данные иллюстрируют постоянное снижение количества животных (оленей и крупного рогатого скота) в собственности аборигенов и одновременный рост численности общественного поголовья. Увеличение колхозного стада шло за счет постепенного обобществления личных животных у аборигенов-колхозников, ежегодного прироста оленей на собственной основе, а также вытеснения малопродуктивного скота якутской породы более продуктивными животными. Эта «тихая» экспроприация личных животных не встречала какого-либо сопротивления со стороны коренных жителей, что объясняется их желанием оказать помощь стране в сложных военных условиях.

Оленеводство как отрасль, наиболее тесным образом связанная с культурной самобытностью коренных жителей, обладала большим социальным и жизнеобеспечивающим потенциалом. Од- 
Таблица 2. Динамика колхозного производства Охотско-Колымского края в годы войны Table 2. Dynamics of collective farm production in the Okhotsk-Kolyma region during the war

\begin{tabular}{|c|c|c|c|c|c|c|}
\hline \multirow{2}{*}{ Показатель } & \multicolumn{6}{|c|}{ Данные на начало года } \\
\hline & 1941 & 1942 & 1943 & 1944 & 1945 & 1946 \\
\hline Поголовье оленей всего, гол. & 29409 & 32291 & 41083 & 42568 & 46135 & 48718 \\
\hline В том числе: & & & & & & \\
\hline общественных & 8226 & 18796 & 26837 & 30680 & 34430 & 38805 \\
\hline личных & 21183 & 15495 & 14246 & 11888 & 11705 & 9913 \\
\hline Крупный рогатый скот, гол.: & & & & & & \\
\hline общественный & 377 & 684 & 649 & 713 & 685 & 768 \\
\hline личный & 759 & 598 & 499 & 362 & 353 & 338 \\
\hline Посевные площади, га: & & & & & & \\
\hline картофеля & 42.7 & 43.4 & 47.8 & 69.1 & 56.4 & 66.8 \\
\hline капусты & 5.2 & 16.6 & 10.6 & 14.7 & 11.5 & 14.4 \\
\hline Валовой сбор, т: & & & & & & \\
\hline картофеля & 135.1 & 261.7 & 317.8 & 303 & 381 & 314 \\
\hline капусты & 23.2 & 149.5 & 194.1 & 182 & 169 & 162 \\
\hline Денежные доходы, тыс. руб.: & & & & & & \\
\hline от рыболовства и охоты & 4457 & 6196 & 8833 & 8197 & 12460 & 8164 \\
\hline от животноводства & 1086 & 1079 & 2342 & 3581 & 4082 & 4713 \\
\hline $\begin{array}{l}\text { Доходы колхозников на одно хозяйство, } \\
\text { тыс. руб. }\end{array}$ & 4.5 & 5.7 & 7.3 & 6.9 & 9.3 & 9.9 \\
\hline
\end{tabular}

Примечание. Составлено по: [ГАМО, ф. Р-38, оп. 1, д. 1, л. 1; д. 46, л. 66].

нако в Охотско-Колымском регионе данная сфера аборигенной экономики имела выраженное транспортное направление, изначально присущее тунгусскому типу оленеводства. В годы советской власти и золотопромышленного освоения транспортная составляющая получила дополнительный импульс, так как олени широко использовались Дальстроем в гужевых перевозках. При этом во вновь созданных охотско-колымских колхозах оленеводство очень долго не могло «встать на ноги» и начать приносить сколько-нибудь существенные денежные доходы. Эта тенденция сохранялась и в первой половине 1940-х гг.

16 сентября 1941 г. органы местной власти принимают решение о развитии оленеводства, которое в предвоенные годы было «...nущзено на самотек, приводивший к большим потерям оленепоголовья, непроизводительному отходу оленей, хищническому забою и огромньм потерям для нашего государства» [ГАМО, ф. Р-23 сч., оп. 1, д.79, л. 48]. К декабрю 1941 г. разрабатываются меры по стимулированию развития оленепоголовья в колхозах национальных районов Дальстроя. Важную роль играл ежегодный конкурс на звание лучшего колхоза и лучшую оленеводческую пастушескую бригаду с вручением переходящего Красного Знамени. Также предусматривалось вручение бригадирам и пастухам грамот Главного и Политического управления Дальстроя с надписью «Знатному оленеводу Колымы» [ГАМО, ф. Р-38, оп. 1, д. 1, л. 69].

В этот период принимается план довести поголовье оленей в колхозном секторе к
01.01.1945 г. до 66 тыс. животных, из них в Ольском районе - 30 тыс., Северо-Эвенском - 24.7 тыс., Среднеканском - 6.6 тыс. Предполагалось также произвести закупку 5 тыс. оленей в Якутии для усиления оленеводческой отрасли в Среднеканском районе. Общественное стадо в целом должно было составить не менее $80 \%$ поголовья [Там же]. Однако эти планы не были полностью реализованы, так как развитие оленеводства оказалось чрезвычайно затратным, и до него в эти тяжелые годы зачастую просто «не доходили руки».

Отметим, что весной 1941 г. на территории, не входившей в зону деятельности Дальстроя, но тесно примыкающей к Северо-Эвенскому району, был образован оленеводческий совхоз «Пареньский», становление которого совпало с военным периодом. Но даже это специализированное хозяйство не могло выпускать продукцию собственно оленеводства, а оказывало стране помощь другого рода. Как писал первый директор совхоза Н. Садченков, «только в одном 1943 г. коллектив совхоза сдал государству 800 и рыбы, 50 и жира морзверя. Охотники добыли и сдали стране пушнины более чем на 20 mblс. руб.» (Советы..., 1982. С. 71, 72).

Наиболее существенным тормозом в развитии оленеводства были ежегодные потери оленей. Так, по Ольскому району за 1943 г. потери составили 2926 гол., в то время как сдача заготовительным организациям - всего 1 тыс. туш. Причины потерь руководители региона видели в недостаточном контроле за работой пастушеских 
бригад (плохо поставленные дежурства, отсутствие твердых маршрутов, плохая изученность оленьих пастбищ) и недостатке внимания со стороны правлений колхозов к нуждам и запросам пастухов (плохое снабжение спецодеждой, палатками, обувью, продовольствием; отсутствие медицинского обслуживания) [ГАМО, ф. П-15, оп. 3, д. 10 , лл. 5, 5об; ф. П-16, оп. 2, д. 18 , л. 20].

Тем не менее определенные усилия для укрепления отрасли были сделаны. В 1942-1945 гг. во многих охотско-колымских оленеводческих хозяйствах практически не производился регулярный плановый забой оленей, за исключением выбраковки: в трудные военные годы государство заботилось о наращивании поголовья даже в ущерб снабжению. Колхозы стремились улучшать учет и отчетность, разрабатывать рациональные маршруты выпаса. В стада были направлены зоотехники, организован ряд ветеринарных пунктов. В новых условиях хозяйствования требовалось также обучать и повышать квалификацию бригадиров и пастухов, для чего были организованы школы по подготовке национальных кадров. Серьезное внимание продолжали уделять обучению транспортных оленей [ГАМО, ф. Р-117, оп. 1, д. 35, л. 2].

В целом в годы войны оленеводство в ОхотскоКолымском крае в значительной мере сохраняло вспомогательную функцию. Олений транспорт служил подспорьем для других отраслей (рыболовство, пушная охота), а также с его помощью выполнялась перевозка грузов для снабжения самих колхозников. Будучи социально очень значимой отраслью, оленеводство значительно уступало другим направлениям колхозной экономики как источник продовольствия и денежных средств. На первый план в отношении натурального снабжения вышло рыболовство, а в финансовом отношении - рыболовство и пушная охота.

Накануне и особенно в годы Великой Отечественной войны рыболовство становится главным направлением развития колхозного производства, принося основную долю дохода. Следует отметить, что национальные колхозы играли ведущую роль в добыче рыбы в ОхотскоКолымском крае, удельный вес их улова в общей рыбодобыче Дальстроя составлял более 60\% (Хаховская, 2008. С. 81). Развитие рыболовства происходило на базе колхозов Ольского и Северо-Эвенского районов, а в Среднеканском районе оно не вышло за рамки любительского промысла для собственного потребления и, частично, продажи на рынке. При этом ольские хозяйства вылавливали преимущественно рыбу лососевых пород, а северо-эвенские - лососевые и сельдь. В предвоенные годы колхозы Ольского района добывали около 60 тыс. ц рыбы ежегодно, а впоследствии вылов из года в год наращивался: в 1941 г. он достиг 84 тыс. ц, а в 1944 г. - 103 тыс. ц. В Северо-Эвенском районе в 1941 г. вылов составил 20 тыс. ц, в 1944 г. 37 тыс. ц (Бацаев, 1997. С. 89, 96, 97).

Техническая вооруженность коллективных хозяйств являлась слабой - не хватало средств передвижения, орудий промысла. В годы войны колхозы прибрежной зоны выходили из положения, арендуя плавсредства и орудия лова у рыбозаводов и других организаций. Нехватка привозных сетеснастей компенсировалась также тем, что колхозы мобилизовывали домохозяекаборигенок плести сети надомно из предоставляемого сырья (дели) [ГАМО, ф. П-16, оп. 2, д. 18, лл. $6,8,15]$. Почти весь улов колхозы сдавали на переработку на рыбозаводы.

Однако в Северо-Эвенском районе с 1943 г. колхозы стали заниматься и обработкой рыбы, благодаря чему высвободили на основное производство Дальстроя около 200 чел. [ГАМО, ф. П-15, оп. 3 , д. 10, л. 3об]. Промышленный лов лососевых здесь вели на рр. Наяхан, Таватум, Вилига; в 1943 г. были открыты промысловые участки на рр. Гижига и Широкая. В места промыслов доставлялись засольные емкости (чаны), для чего еще по снегу использовали оленьи обозы (до 150 оленьих нарт). Над чанами на промыслах сооружались навесы [ГАМО, ф. П-15, оп. 3, д. 6, л. 98].

Труд колхозников на добыче и обработке рыбы был напряженным, а бытовые условия в местах их временного проживания, как правило, неудовлетворительными. Как видно из документов, после тяжелого дня на промысле колхозники вынуждены были ходить далеко от берега («в сопки») за дровами и водой, теряя время и энергию вместо отдыха [ГАМО, ф. П-15, оп. 3, д. 10, л. 20об]. Тем не менее коренные жители в основной своей массе сознательно и добросовестно занимались промыслом. Так, руководители СевероЭвенского района отмечали именно осознанный, добровольный характер труда во имя победы: «Все население района проделало большую рабоmу по рыбе и пушнине. Но они это делали по своей сознательности. В выполнении плана по рыбе и пушнине нами не так много сделано. Вот промысел Вархалам. Там нет парторганизации, а коллектив выполнил план. Ими руководило желание работать на помощьь фронту» [ГАМО, ф. П-15, оп. 3, д. 10, л. 16].

Как и в целом по стране, в трудовой строй становились прежде не работавшие на общественном производстве женщины-аборигенки. Однако возможность привлекать молодых женщин в рыбодобычу (как правило, они обрабатывали рыбу) часто ограничивалась нехваткой детских ясель и садов.

Большое внимание охотско-колымские колхозы стали уделять пушной охоте, так как «nушные заготовки в годы войны приобрели хозяйственнополитическое значение». В 1941-1944 гг. колым- 
ские охотники добыли 677 тыс. экземпляров пушных зверей (белка, горностай, росомаха, медведь, лисица, выдра и др.) (Широков, 2009. С. 286). В Ольском и Северо-Эвенском районах основным видом добычи была белка, в Среднеканском районе из-за небольшой ее численности охотники переключились на заготовку горностая, лисиц и других видов промысловых зверей [ГАМО, ф. П-10, оп. 1, д. 89, л. 63].

В годы войны выявились существенные недостатки в организации пушного промысла. Вопервых, многие охотники не проживали постоянно в охотничьих угодьях, а постоянно возвращались в села, что отнимало много времени и сил. Во-вторых, охотники не имели предписанных маршрутов, поэтому они не уходили в тайгу, а охотились поблизости от сел, в районах с малым запасом пушнины. В-третьих, оставляла желать лучшего оснащенность охотников орудиями промысла, снаряжением и продовольствием. Зачастую полученные продукты охотники оставляли в селе и даже продавали. В результате у них не хватало припасов до конца охотничьего сезона и они возвращались, не выполнив план. Партийные работники отмечали: «B поселках есть случаи, когда приезжие русские граждане скупают за чай и табак талоны на крупу, яичный порошок у местного населения ... Надо не допускать фактов продажи продуктов охотниками в поселках» [ГАМО, ф. П-15, оп. 3, д. 10, л. 21]. Тем не менее, несмотря на эти недостатки, добыча пушнины в военные годы в основном возрастала (табл. 3).

Острой проблемой в пушной добыче стала нехватка промысловиков, что поставило на повестку дня задачу привлекать молодежь и подростков: «Кадры охотников в наших колхозах с каждым днем выбывают. Надо готовить охотников из молодежи» [ГАМО, ф. П-10, оп. 1, д. 89, л. 32]. Существенный влад в увеличение добычи пушного зверя внесли женщины-аборигенки. Руководители Северо-Эвенского района отмечали: «Ежегодно увеличивается число женщин-

Таблица 3. Добыча пушнины в приморских районах Охотско-Колымского края

Table 3. Fur production in the coastal areas of the Okhotsk-Kolyma region

\begin{tabular}{|c|c|c|}
\hline \multirow{2}{*}{ Год } & \multicolumn{2}{|c|}{ Объем добытой пушнины, тыс. руб. } \\
\cline { 2 - 3 } & Ольский район & $\begin{array}{c}\text { Северо-Эвенский } \\
\text { район }\end{array}$ \\
\hline 1941 & 210 & 234 \\
\hline 1942 & 130 & 193.4 \\
\hline 1943 & 256.3 & 293.6 \\
\hline 1944 & 315 & 320.3 \\
\hline 1945 & 252 & $\begin{array}{c}\text { Данные } \\
\text { отсутствуют }\end{array}$ \\
\hline
\end{tabular}

Примечание. Источник: Хаховская, 2008. С. 126. охотников. Если в 1935 году выходило женщуин на охоту шесть, то в 1941 году их вынло 26». По итогам пушного сезона 1942/43 г. отличились охотницы М. П. Мангруни и В. П. Кудрина. Кудрину, как лучшую охотницу, наградили грамотой Главного и Политического управления Дальстроя и значком «Отличнику-дальстроевцу» (Козлов, 1986. С. 70).

Колхозы Среднеканского района специализировались главным образом на животноводстве и огородничестве. Деятельность колхозников затруднялась из-за сложного климата, отсутствия специалистов и оборудования. Посевные площади под основные огородные культуры - картофель и капусту - постепенно расширялись, увеличивалась также их урожайность. Однако производительность колымских колхозов в сфере растениеводства была невысока. Как указывают исследователи, «половина колхозов не обеспечивала потребность в картофеле и овощах даже своих колхозников» (Широков, 2009. С. 287).

Во всех колхозах Среднеканского района были созданы молочно-товарные фермы. Однако местный скот якутской породы отличается малопродуктивностью и нерентабельностью. По этой причине от молочно-товарных ферм колхозы не только не получали прибыль, а, наоборот, постоянно терпели убытки. Более того, они «съедали» значительную часть доходов других отраслей. Хозяйствам поэтому приходилось постоянно выбраковывать скот убыточной якутской породы, вести метисацию, закупать породистых животных [ГАМО, ф. П-10, оп. 1, д. 89, лл. 56, 58]. В результате улучшения породности крупного рогатого скота значительно вырос удой на 1 фуражную корову - с 375.4 кг в 1941 г. до 1318.3 кг в 1946 г. [ГАМО, ф. П-10, оп. 1, д. 140, л. 34]. В итоге колхозы Среднеканского района произвели в 1941 г. около 71 т молока, в 1942 г. - свыше 140 т, в 1943 г. - около 170 т, в 1944 г. - почти 189 т (Козлов, 1986. С. 79). Все же рост животноводства в районе сдерживался недостаточным развитием кормовой базы.

Самым убыточным видом животноводства являлось коневодство. План развития отрасли из года в год не выполнялся из-за крайне низкого приплода. Главная причина такого положения заключалась в том, что значительная часть лошадей в течение ряда лет находилась в аренде на предприятиях Дальстроя и в полевых партиях. Эти лошади, как правило, не давали никакого приплода. Более того, из-за «варварского» отношения арендаторов ежегодно погибало большое количество лошадей [ГАМО, ф. П-10, оп. 1, д. 89, л. 59].

Наряду с отмеченными видами сельхозпродукции, охотско-колымские колхозы обязывались ежегодно организовывать плановый забой морских чаек (100 ц), водоплавающей и боровой дичи (140 и 1700 ц), сбор яиц диких птиц 
(100 тыс. шт.), ягод (530ц), шишек стланика (300 ц), заготовлять до 200 ц мяса диких животных. Особенно высокий потенциал местных ресурсов существовал в Северо-Эвенском районе, но не всегда его можно было реализовать из-за нехватки снаряжения, в особенности боеприпасов: «Нужно обратить внимание и на местные заготовки. На промыслах колхозники могут заготовить в одну минуту несколько десятков чаек, но нет у них дроби» [ГАМО, ф. П-15, оп. 3, д. 6, л. 34].

В целом в военные годы сельское и промысловое хозяйство Охотско-Колымского края значительно увеличило масштабы своей деятельности. Но решить поставленную органами власти задачу полностью обеспечить регион продовольствием колхозы все же не могли. Серьезным препятствием на этом пути являлся суровый климат территории. Формирование местной продовольственной базы сдерживалось также экстенсивными методами ведения хозяйства, неразвитыми технологиями земледелия, добычи и обработки биологических ресурсов.

Определенную роль сыграла также установка на комплексность, равноценное развитие всех отраслей, которая в годы войны выявила свою слабую сторону - хроническую нехватку кадров. Об этом постоянно говорили руководители коллективных хозяйств: «Трудно планировать работу колхоза..., не знаешь, куда вьделить людей, на рыбу или на оленеводство, и везде не хватает рабочих рук, а поэтому с ежегодным увеличением государственного плана по улову рыбы надо придерживаться какого-то определенного количества оленей, а то пастухов не хватает в стадах и поэтому колхоз имеет ежегодные большие потери оленей» [ГАМО, ф. П-15, оп. 3, д. 10, л. 20]; «Сейчас, отправляя охотников на охоту, я должен оголить стада, mо есть оставить в стаде по три пастуха, $u$ тогда мы не можем требовать от пастухов, чтобы не было потерь оленей. Они ответят нам, что мы не справляемся с работой, что на стадо нужно минимум семь человек» [Там же, л. 22].

Такое положение дел приводило к повышенной нагрузке на трудоспособных колхозников, необходимости привлекать к общественным работам подростков, женщин, пожилых людей. Тем не менее в годы войны колхозники-аборигены разделяли со всем советским народом трудовые и бытовые тяготы, общую веру в победу. Партийные руководители отмечали: «Трудовая дисииплина колхозников хорошая - нет случаев отказа от работы или невыхода на работу. Настроение у колхозников боевое» [ГАМО, ф. П-15, оп. 3, д. 6, л. 34].

\section{УЧАСТИЕ В БОЕВЫХ ДЕЙСТВИЯХ И ПОМОЩЬ ФРОНТУ}

Наряду с трудовой ответственностью, у коренных жителей Охотско-Колымского края в годы войны в полной мере проявился патриотизм, готовность жертвовать жизнью во имя победы, участвовать в личной посильной помощи фронту. Тяготы, переживаемые всей страной, отзывались в их сердцах искренней болью и состраданием.

Принятый в сентябре 1939 г. закон «О всеобщей воинской обязанности» не распространялся на представителей коренных северных народов (кроме не входивших в официальный перечень камчадалов). Тем не менее те из коренных жителей, кто выражал настойчивое личное желание защищать родину, призывались в действующую армию. Достоверно неизвестна численность воевавших на фронте аборигенов Охотско-Колымского края. Приблизительная оценка - около 100 человек. Так, в сентябре 1941 г. Ольский военкомат призвал в армию выпускника Охотско-Колымского техникума камчадала Иннокентия Черных. Он участвовал в боях за Украину, Белоруссию, воевал в Восточной Европе. Из с. Тауйск (Ольский район) в действующую армию призван камчадал А. Попов, воевавший в Крыму и Молдавии. Эвен Прокопий Егорович Бабцев из с. Бараборка (Ольский район) ушел на фронт в 1943 г., воевал, был ранен и в июне 1944 г. скончался от полученных ран (Козлов, Райзман, 1996. С. 108).

Летом 1944 г. была призвана в армию группа рабочих рыбных промыслов Северо-Эвенского района. В их числе ушли на фронт местные жители, камчадалы и эвены: В. Духинов, В. Аруев, И. Гурин и А. Трахалев из с. Таватум; братья Семен и Степан Падерины из с. Наяхан; К. Амагачан, С. Буков, И. Филимонов, А. Хеуни из с. Гарманда; А. Буков и Г. Гануни из с. Камешки (Там же. С. 107, 108).

Кроме того, коренные жители служили в тыловых войсках, оборонявших дальневосточные рубежи страны. Представители аборигенов, призванные в 1941-1945 гг. в армию, несли службу во второй отдельной стрелковой бригаде, в 499-м и 540-м стрелковых полках, в 61-м морском пограничном отряде, 22-м стрелковом полку НКВД, в Нагаевском секторе береговой обороны. Эти части дислоцировались в Магадане и поселках Колымы и Охотского побережья (Козлов, 1996. С. 71; Козлов, Райзман, 1996. С. 110).

В годы войны аборигены Охотско-Колымского края стали инициаторами многих патриотических начинаний в помощь фронту. Коренные жители края сдавали в фонд обороны лично им принадлежавшие пушнину, нерпичий жир, шили теплую одежду и другие вещи для бойцов Красной Армии. В течение всех военных лет колхозникиаборигены участвовали в подписках на госу- 
дарственные военные займы 1942-1945 гг., дополнительный заем 1941 г. Зимой 1944 г. эвены, члены колхоза «Имени 23 годовщины Октября» (c. Эсчан Среднеканского района) собрали 50 тыс. руб. на строительство танка [ГАМО, ф. П-10, оп. 1, д. 89, л. 7].

Массовым видом помощи стала сдача личных оленей: средства, вырученные от продажи этих животных в совхозы Дальстроя («Буксунда», «Талая», «Челбанья»), перечислялись в фонд обороны. Так, эвен Павел Иванович Духинов (1911 г. р.), уроженец с. Таватум (СевероЭвенский район), в 1942 г., имея всего 19 оленей, сдал 5 оленей в фонд обороны и 3 оленей на подарки для бойцов Красной Армии [ГАМО, ф. 15, оп. 3, д. 6, л. 62].

В 1944 г. сдали в фонд обороны 265 оленей колхозники Северо-Эвенского района, в том числе: Болдухинов Алексей Федорович - 70; Нерига Василий Яковлевич - 50; Хеуни Роман Кириллович - 55; Болдухинов Николай Ильич - 50; Кендаку Вера Васильевна - 40 [ГАМО, ф. 15, оп. 3, д. 10, л. 2об]. Стоит также упомянуть, что коллектив Охотско-Колымского краеведческого музея отправил бойцам Красной Армии 18 вещей из музейной этнографической коллекции, приобретенной у коренного населения региона (5 пар торбасов, 2 пары меховых чулок, 2 пары меховых рукавиц, 7 кисетов для табака, малахай, меховую шапку).

В целом колхозники Охотско-Колымского края сдали в фонд обороны страны 15398 ед. теплых вещей; 2391 оленя; 3.9 млн руб. в виде облигаций госзаймов; 3.1 млн руб. наличными деньгами; 287.7 тыс. руб. в виде спецвкладов (Козлов, 1986. С. 86). Общественный настрой коренного населения соответствовал общей атмосфере сплоченности и стойкости: «Люди понимают задачи и работают так, как от них требует сейчас Родина» [ГАМО, ф. П-22, оп. 1, д. 97, л. 8].

Трудовой вклад аборигенов в победу над врагом был отмечен высокими наградами: бригадиры колхоза «Новый путь» (с. Бараборка Ольского района) Семен Николаевич Трифонов и Андрей Иванович Трифонов, заместитель начальника административно-гражданского отдела Дальстроя Агапит Алексеевич Кочеров удостоены ордена «Знак Почета»; охотник колхоза «Светлая жизнь» (с. Нелемное Среднеканского района) Афанасий Васильевич Винокуров - медалью «За трудовую доблесть»; бригадир колхоза «Имени III пятилетки» (с. Балыгычан Среднеканского района) Кирик Иосифович Федотов, заведующий оленьим стадом совхоза «Челбанья» Алексей Сергеевич Христофоров, председатель колхоза «Сталинец» (с. Оротук Среднеканского района) Алексей Васильевич Вензель - медалями «За трудовое отличие» (Козлов, 1986. С. 87, 88). Уже в послевоенное время медалью «За доблестный труд в Великой Отечественной войне 19411945 гг.» были награждены 35 членов колхоза
«Новый путь» (с. Таватум Северо-Эвенского района) и 37 членов одноименного колхоза (с. Бараборка Ольского района) (Там же. С. 88).

\section{ЗАКЛЮЧЕНИЕ}

В политике советского государства по отношению к коренным жителям в суровые годы войны ярко проявились черты преемственности с предшествующим периодом: несмотря на огромные трудности, государство направляло значительные средства на улучшение их жизни. В Охотско-Колымском регионе осуществлялись такие меры поддержки аборигенов, как обустройство жилищной и социальной инфраструктуры в местах их проживания, снабжение привозными продуктами и промышленными товарами. Органы власти также способствовали оздоровлению населения, повышению образовательного уровня, освоению новых трудовых навыков и профессиональному росту. Вместе с тем органы власти стремились дисциплинировать трудоспособных аборигенов в рамках нового для них производственного процесса в коллективных хозяйствах, обязать их выполнять плановые задания ответственно, со значительным напряжением сил.

В условиях военного времени повседневное бытовое положение охотско-колымских аборигенов-колхозников и условия их труда были нелегкими. Однако они мирились с трудностями и терпеливо переносили невзгоды. Основная масса колхозников ответственно подходила к выполнению плановых заданий, которые были нацелены на посильную помощь фронту, трудовую мобилизацию всех групп коренного населения, максимальное использование местных ресурсов. В определенной степени можно утверждать, что патриотический подъем в период Великой Отечественной войны способствовал окончательному примирению коренных жителей с утвердившейся колхозно-совхозной системой организации экономики и повседневной жизни.

\section{ЛИТЕРАТУРА}

Анисков В. Т. Война и судьбы российского крестьянства. Вологда ; Ярославль, 1998. 286 с.

Бацаев И. Д. Сельское и промысловое хозяйство Северо-Востока России 1929-1953 гг. Магадан : СВКНИИ ДВО РАН, 1997. 138 с.

Горбулина И. В. Социальная политика советского государства в годы Великой Отечественной войны: (На материалах Сибири) : дис. ... канд. ист. наук. Москва, 2001. 22 с.

Гребенюк П. С. Колымский лед. Система управления на Северо-Востоке России. 1953-1964. Москва : РОССПЭН, 2007. $271 \mathrm{c}$.

Зима В. Ф. Менталитет народов России в войне 1941-1945 гг. Москва : ИРИ РАН, 2000. 277 с.

Исупов В. А., Алексеев В. В. Население Сибири в годы Великой Отечественной войны. Новосибирск : Наука, 1986. 232 с. 
Козлов А. Г. Первые фронтовики // Вспомним всех поименно. Магадан : Кн. изд-во, 1996. Кн. 2. С. 66-72.

Козлов А. Г. Трудовой подвиг тружеников сельского и промыслового хозяйства Колымы в годы Великой Отечественной войны // Краеведческие записки. Магадан : Кн. изд-во, 1986. Вып. 14. С. 66-89.

Козлов А. Г., Райзман Д. И. Коренные северяне на фронтах войны // Вспомним всех поименно. Магадан: Кн. изд-во, 1996. Книга 2. С. 102-110.

Советская повседневность и массовое сознание. 1939-1945. Москва : РОССПЭН, 2003. 472 с

Советь Северо-Востока СССР (1941-1961 гг.) : сборник документов и материалов. Магадан : Кн. издво, 1982. Ч. 2. 327 с.
Хаховская Л. Н. Коренные народы Магаданской области в XX - начале XXI в. Магадан : СВНЦ ДВО PAH, 2008. 229 c.

Хаховская Л. Н. Якуты Магаданской области: формирование отличительной идентичности // Вестник Северо-Восточного научного центра ДВО РАН. 2009. № 3. C. 97-104.

Шалак А. В. Условия жизни и быта населения Восточной Сибири в годы Великой Отечественной войны (1941-1945). Иркутск : Изд-во ИГЭА, 1998. 183 c.

Широков А. И. Государственная политика на СевероВостоке России в 1920-1950-х гг:: Опыт и уроки истории. Томск : Изд-во Томского ун-та, 2009. 460 с.

Поступила в редакичию 19.06.2020 2.

Поступила после доработки 28.07.2020 г.

\title{
INDIGENOUS PEOPLES OF THE OKHOTSK-KOLYMA REGION DURING THE GREAT PATRIOTIC WAR
}

\begin{abstract}
L. N. Khakhovskaya
North-East Interdisciplinary Scientific Research Institute n. a. N. A. Shilo, FEB RAS, Magadan

Based on archival sources, the author analyzes the situation of the indigenous peoples of the Okhotsk-Kolyma territory during the Great Patriotic War. The government continued to implement paternalistic social policies: the development of housing and social infrastructure in the areas where indigenous peoples live, improvement of medical care and education, and vocational training. It is shown that most indigenous peoples, involved with collective farming worked disciplinedly and responsibly in areas related to traditional nature management (reindeer herding, fishing, fur hunting). With their labor and personal donations, the indigenous people made a feasible contribution to the victory. The indigenous peoples also fought on the front and served in the rear troops.
\end{abstract}

Keywords: the Great Patriotic War, the Okhotsk-Kolyma territory, the indigenous peoples of the north, socio-demographic processes, traditional nature management, front, rear.

\section{REFERENCES}

Aniskov, V. T., 1998. The War and the Fate of the Russian Peasantry. Vologda, Yaroslavl [In Russian].

Batsaev, I. D., 1997. Agriculture and Fisheries in the North-East of Russia 1929-1953. Magadan, NEISRI FEB RAS [In Russian].

Gorbulina, I. V., 2001. Social Policy of the Soviet State during the Great Patriotic War: (Based on Materials from Siberia), Avtoref. Diss. ... Kand. Ist. Nauk. Moscow [In Russian].

Grebenyuk, P. S., 2007. Kolyma Ice. Management System in the North-East of Russia, 1953-1964. Moscow, ROSSPEN [In Russian].

Isupov, V. A., Alekseev, V. V., 1986. Population of Siberia during the Great Patriotic War. Novosibirsk, Nauka [In Russian].

Khakhovskaya, L. N., 2008. Indigenous People in the Territory of Magadan Oblast in the $20^{\text {th }}-$ Early $21^{\text {st }}$ Centuries. Magadan, NESC FEB RAS [In Russian].

Khakhovskaya, L. N., 2009. Yakuts of Magadan Oblast: Formation of the Distinctive Identity, Vestnik NESC DVO RAN. 3, 97-104 [In Russian].

Kozlov, A. G., 1986. Labor Feat of Workers of Agriculture and Fishing Industry of Kolyma during the
Great Patriotic War, Krayvedcheskie Zapiski. Magadan, 14, 66-89 [In Russian].

Kozlov, A. G., 1996. The First Front-Line Soldiers, Remember All by Name. Magadan. Book 2, 66-72 [In Russian].

Kozlov, A. G., Raizman, D. I., 1996. Indigenous Northerners on the War Fronts, Remember All by Name. Magadan, Knizhnoe Izdatel'stvo. Book 2, 102-110 [In Russian].

Shalak, A. V., 1998. Living Conditions of the Population of Eastern Siberia during the Great Patriotic War (19411945). Irkutsk, IGEA [In Russian].

Shirokov, A. I., 2009. State Policy in the North-East of Russia in the 1920-1950s: Experience and History Lessons. Tomsk, Tomsk State University [In Russian].

Soviet Daily Routine and Mass Consciousness, 19391945, 2003. Moscow, ROSSPEN [In Russian].

Soviets of the North-East of the USSR (1941-1961), Collection of Documents and Materials, 1982. Magadan, Part 2 [In Russian].

Zima, V. F., 2000. Mentality of Russia's Peoples in the War of 1941-1945. Moscow, IRI RAN [In Russian]. 